\title{
Low US participation clouds AIDS meeting
}

\section{Erika Check, Washington}

The United States has long had a fractious relationship with the biennial international AIDS conferences, and the meeting that opens on 11 July in Bangkok, Thailand, will be no exception.

In 1992, the conference was moved from Boston, Massachusetts, to Amsterdam in the Netherlands because US rules would have prevented participants who were HIV positive from entering the country. The main international AIDS meeting hasn't been held in the United States since.

And this year, the number of US officials and government scientists participating in the meeting has been severely cut. In March, the Department of Health and Human Services said that it would spend $\$ 500,000$ on this year's conference, and send about 50 researchers and officials. By contrast, the agency spent \$3.6 million on the 2002 conference, held in Barcelona, Spain, and sent about 240 people. Health department officials say that the money is better spent fighting AIDS in other ways.

The change is a symbol of the administration's fraught relationship with AIDS activists and researchers. "Spiritually it sends the message that the United States is limiting its participation, and limiting other countries' access to our knowledge and resources," says Judy Auerbach, vice-president for public policy at

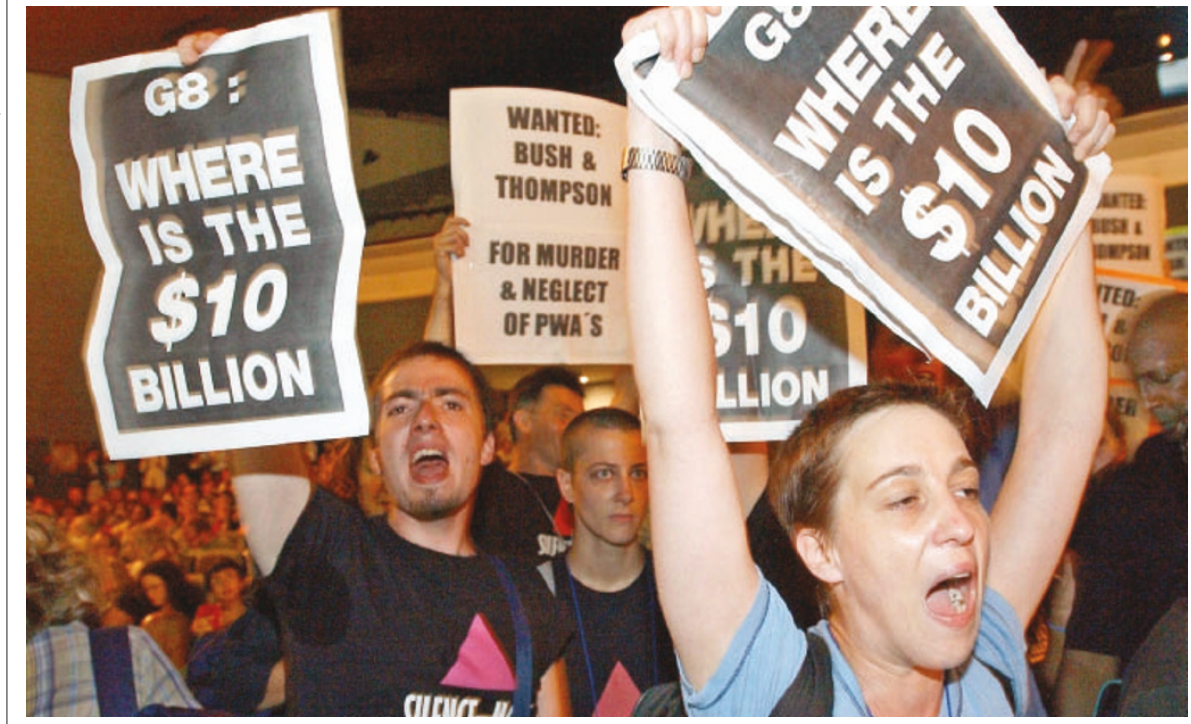

Shouted down: the United States came in for robust criticism during the 2002 AIDS conference.

the American Foundation for AIDS Research, which lobbies for AIDS research funding.

There have been several other skirmishes between the Bush administration and AIDS activists in the run-up to the conference. The activists acknowledge that the administration has continued to fund AIDS research, as well as starting the President's Emergency Plan for AIDS Relief, an ambitious programme to combat AIDS globally. But they contend that Bush's spending on global AIDS has so far fallen short of the $\$ 15$ billion over five years that he promised when he launched the plan in January 2003.

AIDS activists and researchers have also been critical of the Bush administration's attempts to exert direct control over healthrelated programmes. For instance, two weeks ago, it emerged that the health department has enacted a new policy governing how its scientists interact with the World Health Organization (WHO). If the WHO wants to get scientific advice from scientists at agencies such as the National Institutes of Health or the Centers for Disease Control and Prevention, it must now go through the department rather than contacting the scientists directly.

Critics say that more US scientists and officials should be going to Bangkok to talk about such policies. "There's going to be a lot of discussion about these global issues," says Ben Cheng, deputy director of the Forum for Collaborative HIV Research, a Washingtonbased group that sponsors meetings on AIDS. "But the groups that are supposed to take a leadership role around HIV are the ones that aren't going to be there."

For more on the AIDS conference, see page 133.

\section{Biochemist takes the reins at top European laboratory}

\section{Quirin Schiermeier, Munich}

Europe's flagship molecular biology lab has chosen an insider — Iain Mattaj — to be its fourth director.

Mattaj, a Scot, will succeed Greek biologist Fotis Kafatos as director general of the European Molecular Biology Laboratory (EMBL) based in Heidelberg, Germany, next May. European biologists welcomed the institute's appointment of one of its own researchers as confirmation that the 30 year-old laboratory has found its feet.

"It's a terrific choice," says Michael Ashburner, a geneticist at the University of Cambridge, and former co-director of the European Bioinformatics Institute (EBI) near Cambridge, UK, one of EMBL's four outstations. "It's a tough job, but Mattaj has the skills and credibility it will take."

Mattaj, a biochemist, is one of the most- cited biologists in his field. He joined EMBL as a group leader 19 years ago and later led the lab's gene-expression programme, becoming its scientific director in 1999. Colleagues describe him as straightforward, humorous and warm, and many say that he is an ideal director for EMBL.

Mattaj says that his priority will be to accelerate a shift in the lab's focus from the molecular biology of individual genes and proteins to systems biology. "Simulation and computer models are penetrating molecular biology with might," he says. "But there's still much good experimental biology that doesn't use computational methods: this tension must be overcome in the next few years."

EMBL is funded by 17 member states, including most of the western European Union, Switzerland and Israel. Its 100 groups, with about 900 scientists, $\mathrm{PhD}$ students and technical staff, work across the spectrum of molecular biology. Besides its headquarters in Heidelberg and the EBI, EMBL operates X-ray facilities for molecular structural biology in Grenoble, France, and Hamburg, Germany, and a mouse-biology programme in Monterotondo near Rome.

The EMBL council last week agreed to postpone by one year the start of the lab's next five-year science programme to give Mattaj time to prepare the right strategy.

He says that he will try to raise extra money for renovation and expansion: the Heidelberg labs need refurbishment, for example. But Mattaj is keen to continue his own cell-biology work. "I sincerely hope I'll still be able to spend some time in the lab," he says. "Otherwise, it is very easy to forget how difficult it is, and how many disappointments are lurking at the bench." 